Proc. Estonian Acad. Sci. Biol. Ecol., 2003, 52, 3, 173-192

\title{
Benthic release of phosphorus and its relation to environmental conditions in the estuarial Gulf of Finland, Baltic Sea, in the early 2000s
}

\author{
Heikki Pitkänen $^{\mathrm{a} *}$, Jouni Lehtoranta ${ }^{\mathrm{a}}$, Heikki Peltonen ${ }^{\mathrm{a}}$, Ari Laine ${ }^{\mathrm{b}}$, \\ Jonne Kotta ${ }^{c}$, Ilmar Kotta ${ }^{c}$, Pavel Moskalenko ${ }^{\mathrm{d}}$, Anita Mäkinen ${ }^{\mathrm{e}}$, \\ Pentti Kangas ${ }^{\mathrm{a}}$, Matti Perttilä ${ }^{\mathrm{b}}$, and Mikko Kiirikki ${ }^{\mathrm{a}}$
}

${ }^{\text {a }}$ Finnish Environment Institute, BOX 140, FIN-00251 Helsinki, Finland

${ }^{\mathrm{b}}$ Finnish Institute of Marine Research, BOX 33, FIN-00931 Helsinki, Finland

${ }^{\mathrm{c}}$ Estonian Marine Institute, Marja 4D, 10617 Tallinn, Estonia

${ }^{d}$ All-Russian Geological Institute, Sredny Pr. 74, St. Petersburg 199026, Russia

${ }^{\mathrm{e}}$ WWF-Finland, Lintulahdenkatu 10, FIN-00500 Helsinki, Finland

Received 9 April 2003, in revised form 26 June 2003

\begin{abstract}
After the mid-1990s the phosphorus concentrations and budget of the Gulf of Finland have been strongly affected by the enhanced benthic $\mathrm{P}$ input caused by reduced conditions at the sediment-water interface. Especially in late summers and autumns of 1996 and 2001 the total areas of reduced bottom sediments were large enough to affect the $\mathrm{P}$ concentrations of the whole gulf. The total benthic release of phosphate-P, on an annual level, can be several times higher than the bioavailable $\mathrm{P}$ load from the catchment of the gulf. The area of reduced surface sediments varies considerably both spatially and from year to year, especially in the relatively shallow eastern gulf. The intensity of the internal $\mathrm{P}$ loading is greatly controlled by vertical stratification, bottom topography, organic matter content of the sediment surface layer, and the abundance of benthic fauna. Evidently the sediment efflux can strongly affect the annual P balance and dynamics of the Gulf of Finland and counteract the decreases in the external P loading. This is verified both by inter-annual concentration changes and experimental results. The only way to reduce the benthic release of nutrients is to decrease primary production and the succeeding sedimentation of organic matter via further cutting external nutrient inputs both directly to the Gulf of Finland and to the Baltic Proper, which is an important source of nutrients for the gulf.
\end{abstract}

Key words: sediment efflux, phosphorus, nitrogen, benthic fauna, Baltic Sea.

\footnotetext{
*Corresponding author, Heikki.Pitkanen@ymparisto.fi
} 


\section{INTRODUCTION}

Anthropogenic nutrient flows from the catchment area cause eutrophication and pose a major threat to coastal and marine ecosystems (e.g. Nixon, 1995). The Baltic Sea receives nutrients from the drainage area of about four times the sea area itself and it belongs - together with the coastal North Sea and some other restricted coastal water areas - to the most eutrophied marine waters in Europe (Ærteberg et al., 2001). The eutrophying effects of nutrient loading vary depending on the natural conditions of the receiving waters. The Baltic Sea is sensitive to eutrophication due to the high external nutrient load compared to the small water volume and long residence time of this enclosed sea. Density stratification subjects deep waters to anoxia and the accumulation of phosphorus (Fonselius, 1969), which is a common feature for coastal and marine waters with restricted deep water renewal.

The Gulf of Finland (Fig. 1) is the most eutrophied sub-basin of the Baltic Sea (HELCOM, 2002). Nutrient inputs into the gulf relative to its surface area are 2 to 3 times the average inputs of the Baltic Sea (HELCOM, 1998). Additionally, due to the estuarine nature of the gulf, the input of nutrients from the Baltic Proper together with prevailing stratification conditions strongly regulates its state. Two land-based sources of nutrients are of primary importance: the St. Petersburg proper with its 4.5 million inhabitants, and the Neva River drainage basin, covering about $80 \%$ of the whole catchment of the gulf (Kiirikki et al., 2002, 2003).

Before the 1990s, only little scientific information was available on the behaviour of the eastern Gulf of Finland ecosystem and factors controlling its eutrophication. The role of the Neva estuary, receiving most of the external nutrient loading of the whole gulf, was largely unknown. Estuaries and coastal waters can act either as sinks or sources for external nutrient inputs (e.g. Seitzinger, 1988; Froelich, 1988; Balls, 1994; Prastka et al., 1998). Under good oxygen conditions the Neva estuary and the eastern Gulf of Finland have proved to effectively retain nutrient fluxes from the river and from St. Petersburg, and thus decrease the nutrient input to the western gulf and the Baltic Proper (Pitkänen et al., 1993; Pitkänen \& Tamminen, 1995). However, during the mid1990s the strengthened stratification led to reduced conditions on large bottom areas of the Gulf of Finland and voluminous release of nutrients, especially phosphorus took place (Pitkänen et al., 2001; Lehtoranta, 2003), triggering extensive blue-green algal blooms after the mid-1990s (Kahru et al., 2000).

The chemical and biological processes behind the benthic release of phosphorus under reduced conditions are not precisely known (Roden \& Edmonds, 1997; Golterman, 2001; Lehtoranta, 2003). However, it is evident that benthic P retention is favoured when the sediment surface is oxidized, although the process is more effective for freshwater than for marine sediments (Caraco et al., 1990). Oxic conditions are also needed for denitrification, because it receives nitrate, although the actual process is anaerobic (Kemp et al., 1990; Kuparinen \& Tuominen, 2001). In coastal marine waters the state of the sediment surface depends on both the density stratification and the oxygen consuming organic load that settles out from 
the productive surface layer. Also, bioturbation by macrofauna greatly increases the thickness of the oxidized sediment surface and affects sediment geochemistry (e.g. Rosenberg, 2001). If the oxygen conditions allow the existence of macrofauna, this activity may both increase the binding of phosphorus (Hansen et al., 1998) and enhance denitrification (Tuominen et al., 1998; Gran \& Pitkänen, 1999).

Modelling studies suggest that it is possible to reduce the present trophic state of both the whole Baltic Sea and the Gulf of Finland by cutting nutrient fluxes, but the recovery will be slow for the Baltic Proper and its open coasts (Savchuk \& Wulff, 1999; Kiirikki et al., 2001, 2002). According to the modelling scenarios a substantial recovery can take place in the open Gulf of Finland within a few years on condition that major pulses of internal nutrient loading do not counteract the decreased loads (Pitkänen et al., 2001). However, the sediment-water dynamics of nutrients is still poorly known in the whole basin scale, which weakens the reliability of modelling scenarios.

In the present study we assess the benthic release of phosphorus and its controlling factors on P concentration variations and budget in the Gulf of Finland, based on both new and earlier published experimental data. The main hypothesis of the present work is that a strong connection exists between $\mathrm{P}$ concentration variations and benthic conditions in the scale of the whole gulf.

\section{MATERIAL AND METHODS}

\section{The study area}

The Gulf of Finland (area $30000 \mathrm{~km}^{2}$; Fig. 1) is geomorphologically a direct continuation of the Baltic Proper without any sills. Hydrographically the sea area, and especially its easternmost part, can be regarded as a partially mixed estuary, because of its topography and the mean fresh water inflow of about $2500 \mathrm{~m}^{3} / \mathrm{s}$ from the Neva River. The open waters of the gulf can be divided into the deeper western (more marine) and shallower eastern (more fresh water affected) parts. The estuarial nature is very distinct in the easternmost waters, east of the island of Seskar (Fig. 1), where also most of the land-based nutrients enter (Pitkänen et al., 1993).

The average theoretical residence time of water for the whole gulf is about 3 years, while it is about one year for the eastern gulf. The surface salinity increases from 0 (pure river water) in easternmost Neva Bay to ca. 6 PSU in the western gulf, whereas near the bottom the salinity increases from 5 PSU in the east to 9 PSU in the west (Pitkänen et al., 1993; Perttilä et al., 1995). The strength of halocline varies both temporally and spatially being the strongest in the deep western gulf. In the eastern gulf the halocline is usually weak or totally absent. During the late 1990s there was a general tendency towards stronger haloclines both in the Baltic Proper and in the Gulf of Finland (Elken et al., 2002; Lips et al., 2002). The gradually increasing salinities towards the bottom below the mixed surface layer indicate slow but almost continuous vertical mixing between the outflowing surface and inflowing deeper water layers, especially in the Neva 


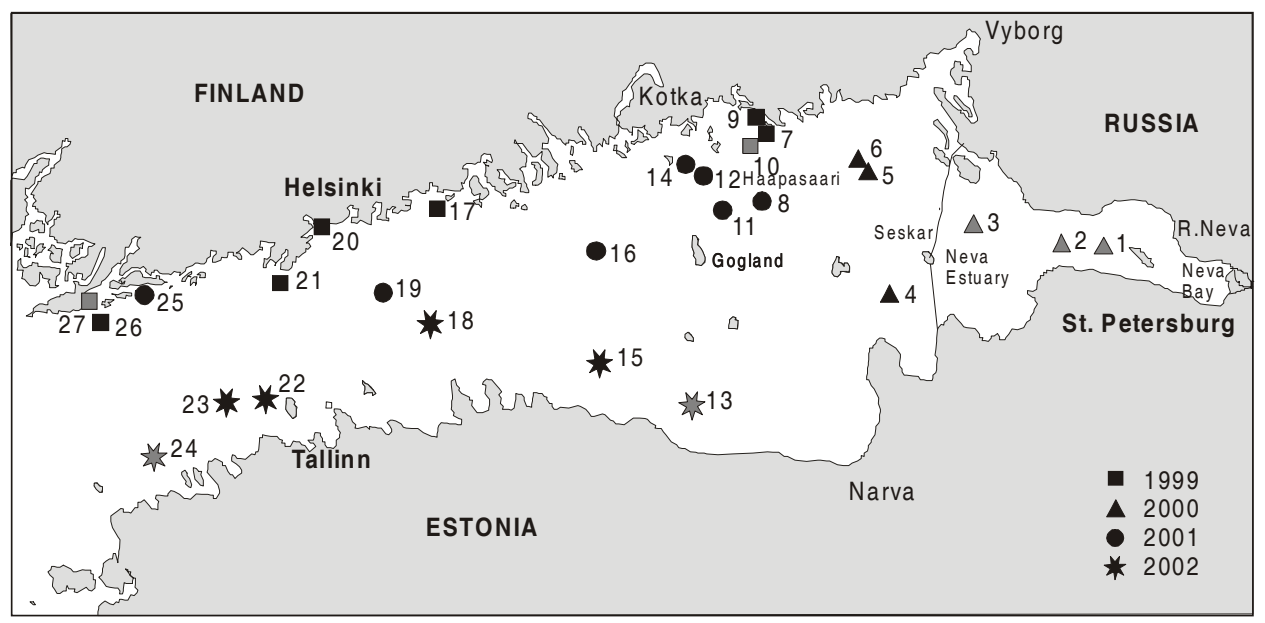

Fig. 1. The study area. Sampling stations for the sediment-water flux measurements are marked by numbers from 1 to 27 and by symbols indicating the sampling year. Grey symbols denote oxidized sediments (i.e. sampling sites with a brown oxidized surface layer) and black symbols anoxic reduced sediments (i.e. sampling sites where the black layer extended to the surface of sediment).

estuary, where both the water depth and the vertical salinity differences are smaller than in the deep western parts of the gulf.

Winter concentrations of nutrients in the Gulf of Finland are among the highest of the whole Baltic Sea area (Lips et al., 2002). As a result, the vernal production of organic matter is high in the whole gulf. The sedimentation of autochthonous organic matter is the highest in the eastern gulf, especially in the Neva estuary due to the continuous and strong input of new nutrients to the estuary (Heiskanen et al., 1999).

The poorest deep-water oxygen conditions usually prevail in the middle and western gulf due to the most stagnant deep waters (Andersin \& Sandler, 1991; Perttilä et al., 1995). In these areas relatively strong linear correlations can be found between near-bottom salinity, oxygen, and phophorus (Perttilä et al., 1995). In the shallower eastern gulf as well as in the coastal waters there seem to be substantial deviations from this relationship (Pitkänen et al., 2001).

\section{Monitoring data}

Data of an intensive station monitored by the South-East Finland Regional Environment Centre in the open part of the eastern Gulf of Finland (depth $65 \mathrm{~m}$ ) south from the island of Haapasaari (station 8 in Fig. 1) were used to describe the long-term changes in oxygen, salinity, inorganic phosphate (phosphate-P), and inorganic nitrogen (ammonium-N, nitrate+nitrite-N) in 1980-2002. The station represents the open eastern gulf, having in general better conditions for the 
retention and removal of nutrients than the deeper western gulf, which is more sensitive to reduced conditions due to the direct influence of the deep saline inflow from the Baltic Proper (see Introduction). Only late summer (July-September) data were included in the assessment of long-term changes because this period usually represents the lowest annual oxygen concentrations.

\section{Spatial surveys in 2000-02}

Four cruises were performed with the RV Muikku in August-September 2000-02 in order to survey the spatial variations of salinity and oxygen and nutrient concentrations, as well as for the studies on sediment-water fluxes in the coastal and open waters of the Gulf of Finland (Figs. 1 and 2). Additionally a cruise in the southern Finnish coastal waters in August 1999 was made to study the role of benthic nutrient fluxes in these waters (Fig. 1). A part of the results were published earlier by Pitkänen et al. (2001) and Lehtoranta (2003).

During the cruises salinity and oxygen were measured with a CTD sonde (SeaBird). Phosphate-P and ammonium-N were analysed spectrophotometrically (Koroleff, 1976) and nitrite+nitrate-N by the LaChat QuickChem 8000 Automatic Ion Analyser based on flow injection analysis colorimetry.

During the cruises macrozoobenthos was sampled with a van Veen grab $\left(0.1 \mathrm{~m}^{2}, 1\right.$ replicate) or a Box-corer $\left(0.04 \mathrm{~m}^{2}, 1-3\right.$ replicates $)$. The samples were sieved on a $1.0 \mathrm{~mm}$ screen, preliminarily identified and counted for species, and preserved in $4 \%$ buffered formalin solution for further analysis. These preliminary counts were used for a coarse categorization of the abundance and species number to describe the state of the communities and the occurrence of the amphipod species (Monoporeia affinis and Pontoporeia femorata pooled).

The samples were further analysed for species, numbers, and biomass at the Finnish Environment Institute and at the Estonian Marine Institute in order to confirm the reliability of the preliminary observations and the validity of the categorized data. A more detailed study on the species composition and biomasses will be published separately.

\section{Nutrient flux experiments}

In order to estimate the role of sediments in the nutrient budget of the Gulf of Finland, sediment cores for the benthic flux measurements of dissolved inorganic phosphate (DIP), $\mathrm{NH}_{4}-\mathrm{N}$, and $\mathrm{NO}_{2}+\mathrm{NO}_{3}-\mathrm{N}$ were taken during the late summer cruises in 1999-2002 with a gravity corer in polycarbonate tubes $(\varnothing 74 \mathrm{~mm})$ from 27 sites in all (Fig. 1). From all sites, 2 or 4 replicate samples were taken and incubated in dark clima-rooms at in situ temperature within 2 hours after sampling using a flow-through sediment incubator. The incubation, analytical procedures, and the technical device used in the experiments are described by Lehtoranta (2003) and Lehtoranta \& Heiskanen (2003). 


\section{RESULTS AND DISCUSSION}

\section{Spatial and temporal variations in near-bottom salinity, oxygen, and inorganic $\mathbf{P}$ and $\mathbf{N}$}

Strong spatial variations were observed in all the measured variables. Salinity followed depth variations and showed the well-known east-west and coastal waters-open sea gradients (Fig. 2a). The highest values between 9 and 10 PSU were measured from the deepest $(>80 \mathrm{~m})$ parts of the southwestern gulf in August 2002. In the same areas oxygen concentrations (Fig. 2b) were low $(<1 \mathrm{mg} / \mathrm{L})$, while phosphate-P (Fig. 2c) and ammonium-N (Fig. 2d) showed strongly enhanced values, for both nutrients up to $200 \mu \mathrm{g} / \mathrm{L}$ indicating reduced conditions at the sediment-water interface.

Near the shallower northern (Finnish) coast the highest near-bottom salinities at 60 to $70 \mathrm{~m}$ were about 3 PSU lower than by the southern deep Estonian coast. The difference can be explained by the larger water depth (up to $100 \mathrm{~m}$ ) in the SW gulf, but evidently also by a strong inward flow of saline water from the Baltic Proper along the southern coast of the gulf in late summer 2002.

The near-bottom oxygen values (Fig. 2b) varied a lot, mostly reflecting the strength of salinity stratification and local morphometrical features of the sampling site. In August 2002 low values $(<3 \mathrm{mg} / \mathrm{L})$ were observed mostly from the deep $(>80 \mathrm{~m}$ ) southwestern and middle gulf, where exceptionally high salinities (9-10 PSU) prevailed. According to the August 2001 data low oxygen values were found in the northeastern gulf at depths of 50 to $70 \mathrm{~m}$. A clear halocline was found at 30 to $40 \mathrm{~m}$ in these areas. In both years low values were measured also from some of the local basins by the northern coast.

According to the data of September 2000, the near-bottom oxygen concentrations of the Russian waters of the eastern gulf were considerably higher ( 4 to $6.5 \mathrm{mg} / \mathrm{L}$ ) than those of the middle open gulf measured during the same cruise, despite the evidently elevated flux of oxygen consuming organic matter at the eastern bottoms (Heiskanen et al., 1999). The absence of permanent halocline and shallower depths (mostly 40 to $60 \mathrm{~m}$ ) than in the west are probably the most important reasons for this. In addition, the density stratification was weaker during the cruise in 2000 than a year later.

On the basis of the values measured in the Finnish and international waters of the eastern Gulf of Finland in August 2001, the area of reduced bottom probably covered a major part of the sediment accumulation bottoms of the gulf in August 2001 (Fig. 2b). As suggested by the extensive near-bottom oxygen depletion and the lack of benthic fauna at most of the stations near the Finnish-Russian borderline (see Changes in macrozoobenthos), the area of reduced bottoms was

Fig. 2. The distribution of near-bottom (a) salinity, (b) oxygen, (c) phosphate-P, (d) ammonium-N, and (e) nitrate+nitrite-N in the Gulf of Finland in August-September 2000-02. The distributions are presented as concentration classes and the different years are indicated with different symbols (2000 black, 2001 white, 2002 grey). Because of the year-to-year variations in physical conditions the results of the different years are not directly comparable with each other. 





probably considerable in the whole open deep part $(>50 \mathrm{~m})$ of the eastern gulf in late summer 2001 (Fig. 2b).

Both phosphate-P and ammonium-N (Figs. 2c and d) varied strongly between the extremes from less than $25 \mu \mathrm{g} / \mathrm{L}$ to about $800 \mu \mathrm{g} / \mathrm{L}$ for both nutrients. For ammonium-N the highest concentrations (400 to $800 \mu \mathrm{g} / \mathrm{L}$ ) were found from semi-enclosed coastal basins by the northern Finnish coast while for phosphate-P also the deep open waters all over the gulf showed strongly elevated concentrations between 100 and $200 \mu \mathrm{g} \mathrm{P} / \mathrm{L}$ and even higher. In contrast to the middle and western parts of the gulf (Perttilä et al., 1995), the relationships of ammonium and phosphate to the ambient near-bottom oxygen seemed to be generally quite poor (cf. Fig. 2b; see Pitkänen et al., 2001).

In the deep parts of the Gulf the highest nitrate+nitrite-N values (about $200 \mu \mathrm{g} / \mathrm{L}$, Fig. 2e) were measured at those stations where good oxygen conditions prevailed (Fig. 2b). At the stations of low oxygen concentrations also nitrate concentrations were low, indicating that nitrate was used in microbial oxidation of organic matter (Lehtoranta, 2003). In the northern coastal waters low values $(<50 \mu \mathrm{g} / \mathrm{L})$ were usual despite modest oxygen concentrations (about $5 \mathrm{mg} / \mathrm{L}$ ), probably due to the reduced conditions at the sediment-water interface, indicated by the measured high ammonium and phosphate concentrations at the same stations, as well as the high measured sediment effluxes of these nutrients (see Sediment-water exchange).

The temporal variations in 1980-2002 of the open northeastern gulf south of the Haapasaari Islands can be divided into two different stages. In the 1980s deep-water salinities (Fig. 3a) decreased and oxygen concentrations increased (Fig. 3b). Along with enhanced oxygen conditions, also an average decrease was evident in phosphate-P concentrations. During the first half of the 1990s deepwater salinities started to increase again, while oxygen concentrations showed an average decrease. At the same time also phosphate concentrations started to increase. The increase in ammonium-N in the 1990s (Fig. 3d) is related to declined oxygen concentrations as well (see Sediment-water exchange). Because of this increase in phosphate concentrations as well in the 1990s, and, on the other hand, because of the relatively even distribution of inorganic $\mathrm{N}$ after an average increase in the 1980s, the inorganic N:P ratio clearly decreased in the 1990s (Fig. 3e).

Most of the high late summer (July-September) phosphate and ammonium values in the near-bottom water at the Haapasaari monitoring station (Fig. 1) were measured between the mid-1990s and 2001 (Fig. 3c and d). Very strong year-toyear variations were typical of this period, which reflects the strongly varying physical and biogeochemical conditions of the whole eastern Gulf of Finland. Naturally, the increased sampling frequency after the mid-1990s "helped" to detect extreme concentrations. However, the possible false effect of the intensified sampling is largely prevented by the use of seasonally selected data.

Fig. 3. Temporal variations of late summer (a) salinity, (b) oxygen, (c) phosphate-P, (d) ammonium-N, and (e) inorganic N:P ratio in the near-bottom water of the Haapasaari sampling station in the eastern Gulf of Finland (station 8, Fig. 1). Samples were taken 1 to $2 \mathrm{~m}$ above the sediment surface. Data produced by the South-East Finland Regional Environment Centre. 




\section{Changes in macrozoobenthos}

Macrozoobenthic communities were absent or very poorly developed in many parts of the Gulf of Finland, especially in the deep southern part (Fig. 4a). More diverse communities of the eastern Gulf of Finland opposed to less diverse or totally absent communities of the central and western gulf. However, strongly impoverished communities or bottoms without macrofauna were also found in shallow coastal basins of the northern Finnish archipelago. This indicates the importance of local morphology and restricted near-bottom water exchange. The amphipods Monoporeia affinis and Pontoporeia femorata (Fig. 4b) were found only in less than a half of the investigated sites, and only in small numbers compared to the densities in the open sea during the early 1990s (Laine et al., 1997). Especially M. affinis is known to be sensitive to low oxygen concentrations (Johansson, 1997; Modig \& Ólafsson, 1998).

In general, oxygen concentrations in the near-bottom layer explained well the variability in the spatial distribution of macrozoobenthos (Figs. 2b, 4a, b). The macrobenthic communities were usually found only in the areas where the oxygen concentrations were higher than $3 \mathrm{mg} / \mathrm{L}$. However, in some cases, especially by the northern coast, the sediment surface was black, indicating reduced condition, and macrozoobenthos was not found in areas where the oxygen concentrations about $1 \mathrm{~m}$ above the sediment surface were relatively high, around $6 \mathrm{mg} / \mathrm{L}$. This result indicates a strong vertical gradient of oxygen within some decimetres above the bottom, caused by the oxygen consumption of sedimented organic matter.

The low abundance or total absence of burrowing benthic species (Fig. 4b) seemed to be affected by the weakened oxygen conditions very close to the sediment surface. The abundances of benthic animals were exceptionally high in the open Gulf of Finland in 1991-95 (Laine et al., 1997; Kotta et al., 2002) during the period of a weak or absent halocline. After the increased deep-water salinity in 1996, there was a drastic decrease in abundances in 1996-97 (A. Laine, pers. obs.). Later very low abundances and total absence of benthic animals have been observed in large areas of the middle and western gulf (unpublished data of the Finnish Environment Institute and the Finnish Marine Research Institute; Fig. 4a).

Also in the southwestern gulf the abundance of macrozoobenthos has gradually declined from 1996 onwards (J. Kotta, pers. obs.). Since 1999 the distribution area of macrozoobenthos has notably declined in the western and central parts of the Gulf of Finland. Changes have taken place at the species level as well. Owing to the inflow of more saline waters from the Baltic Proper, the polychaete Harmothoe sarsi colonized the whole southern gulf in 2001, while the species had not been found in the area since 1995. In 2002 macrozoobenthos spread again

slightly towards deeper areas of the central and eastern Gulf of Finland (Database of the Estonian Coastal Monitoring).

In the present material from the southern part of the Gulf of Finland from August 2002 the species that tolerated best the hypoxic events was the polychaete $H$. sarsi followed by the bivalve Macoma balthica, the isopod Saduria entomon, and the amphipods Monoporeia affinis and Pontoporeia femorata (J. Kotta, pers. obs.). 




(a) Abundance classification

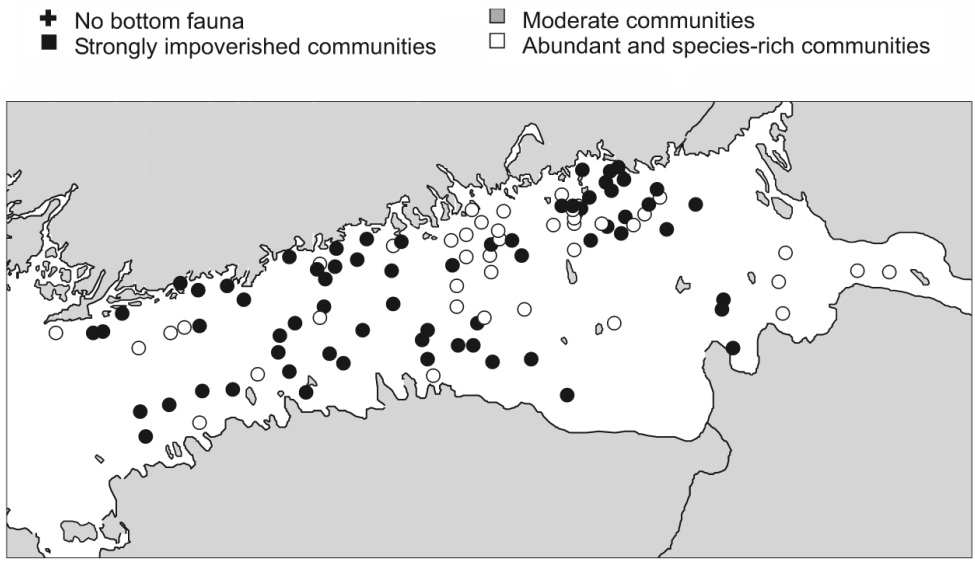

(b) Occurrence of Pontoporeia and Monoporeia

- Absent O Present

Fig. 4. The distributions of benthic fauna abundance (a) and occurrence of Monoporeia/Pontoporeia (b) in samples taken in August-September 2000-02.

Similarly, the North American polychaete Marenzelleria viridis was among the first colonizers of the deserted bottoms. However, in the present material the species did not inhabit depths below $65 \mathrm{~m}$.

\section{Sediment-water exchange}

Sediment-water exchange was measured at a total of 27 stations from both coastal and open sea areas of the Gulf of Finland in 1999-2002 (Figs. 1 and 5; Lehtoranta, 2003). The results demonstrate strong variations in the average phosphate fluxes between oxidized and reduced sediment surfaces. In the case of reduced sediment, the mean DIP efflux of $13 \mathrm{mg} \mathrm{P} / \mathrm{m}^{2}$ per day was obtained for 


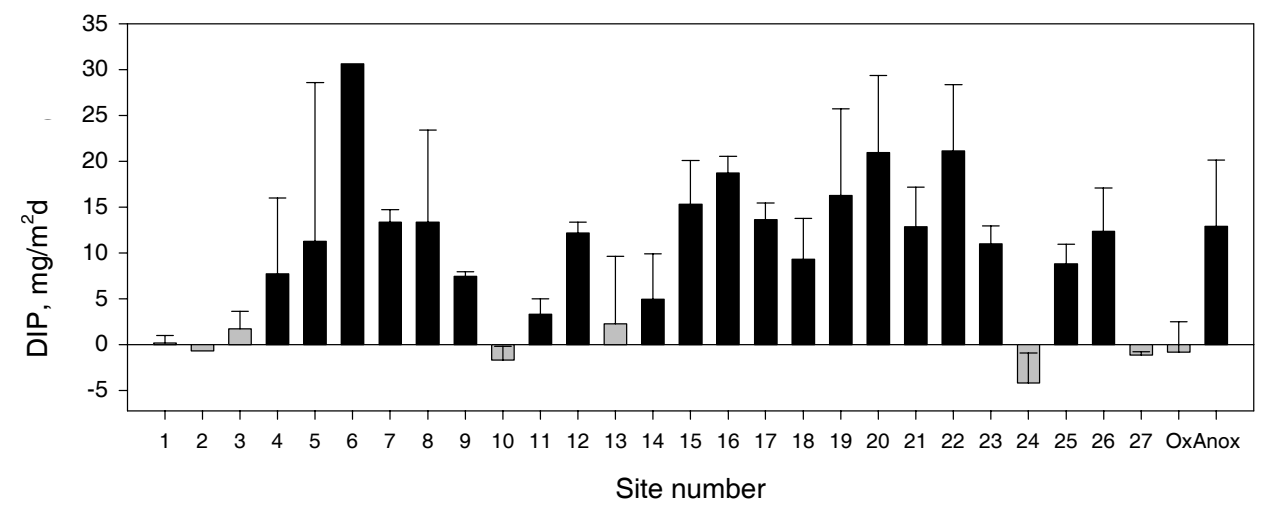

Fig. 5. Benthic flux of DIP in the Gulf of Finland from four separate cruises in 1999-2002. Grey bars denote oxidized sediments (i.e. bottoms with a brown oxidized layer) and black bars anoxic reduced sediments (i.e. bottoms where a black layer reached the surface of the sediment). Ox denotes average benthic flux of $\mathrm{P}$ from water to sediment at oxidized bottoms and Anox the corresponding flux from sediment to water at the anoxic sediments. The error bars denote standard error of the mean. Data from Lehtoranta (2003).

the whole data set, while in the case of the oxidized sediment surface the mean value was $0.5 \mathrm{mg} \mathrm{P} / \mathrm{m}^{2}$ per day from water to sediment.

In the present data the high effluxes were - with no exceptions - connected with the reduced, black-coloured sediment surface at 20 out of the 27 stations. Except the Neva estuary (Fig. 1), reduced conditions seemed to prevail in large areas of organic accumulation bottoms of the gulf, both in open and coastal areas. Additionally, the sediment surface was often colonized by white bacteria (probably filamentous sulphur oxidizing Beggiatoa spp.), indicating very low oxygen concentrations in the water layer immediately above the sediment surface, although several milligrams per litre were measured from samples taken at about $1 \mathrm{~m}$ above the bottom.

The absence of an oxidized surface layer and the measured high effluxes of phosphate and ammonium are probably related to the oxygen consumption caused by the high organic matter concentration of the surface sediment (Fig. 6),


Fig. 6. Correlations between sediment organic matter and benthic efflux of $\mathrm{NH}_{4}-\mathrm{N}$ and DIP (Lehtoranta, 2003). Data from stations 1 to 6 (see Fig. 1). 

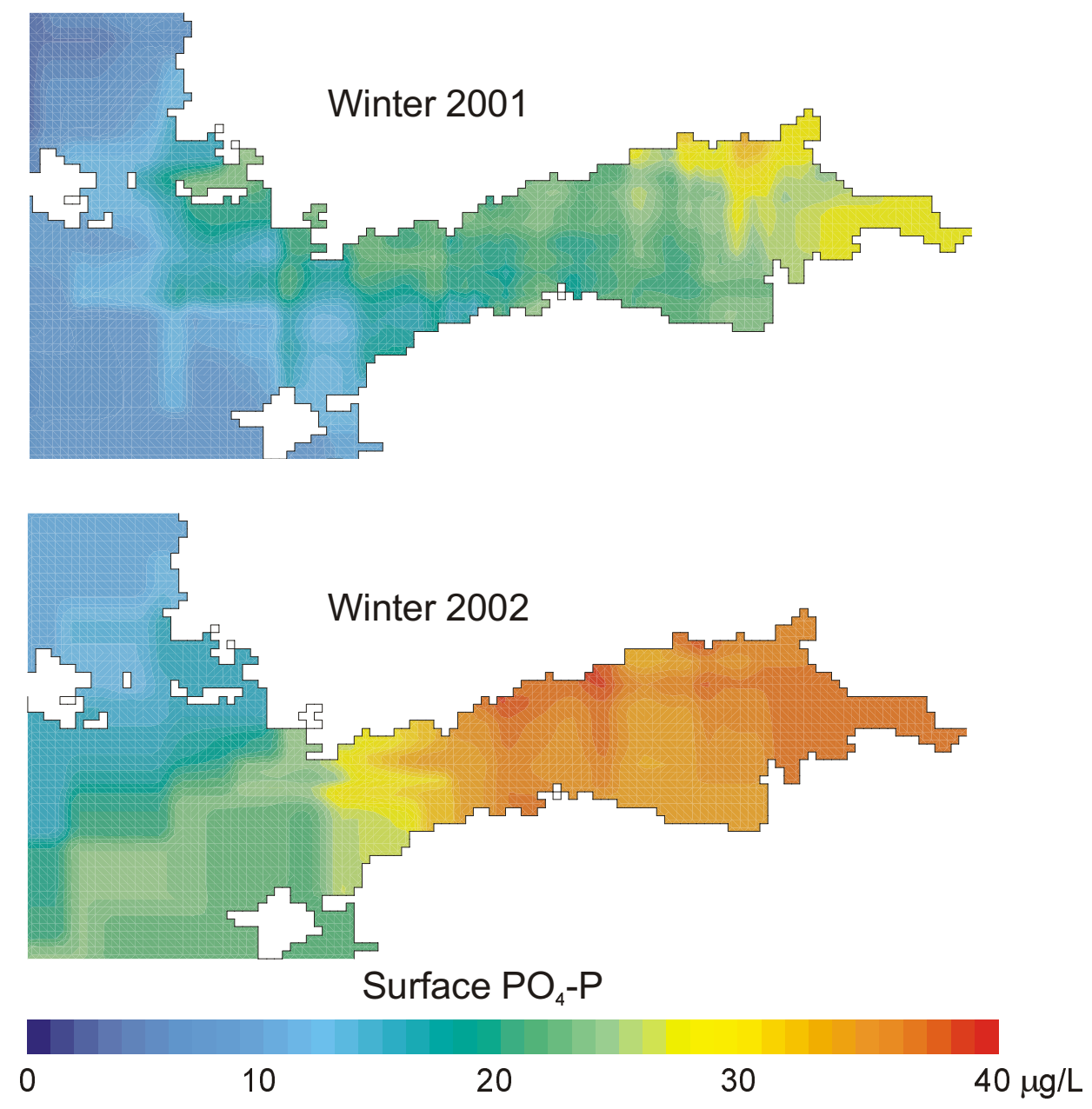

Fig. 7. Phosphate-P concentration distributions in the surface layer (0 to $20 \mathrm{~m})$ of the Gulf of Finland in winters (January-March) 2001 and 2002 (material from the Finnish Environment Institute, Finnish Institute of Marine Research, the Southeast Finland Regional Environment Centre, the Uusimaa Regional Environment Centre, the Southwest Finland Regional Environment Centre, and the City of Helsinki). 

and to the strong vertical density difference hindering the renewal of near-bottom water. Long-term variations in deep-water salinity, oxygen, phosphate, and ammonium (Fig. 3) indicate that reduced/hypoxic areas have become larger in the Gulf of Finland since the first half of the 1990s.

The development is, especially in the western gulf, related to the seawater pulses from the North Sea to the Baltic Sea in 1993-94 (Matthäus \& Lass, 1995) and the following intrusion of saline water from the Baltic Proper to the Gulf of Finland, causing the strengthening of density stratification (Kahru et al., 2000). In addition to the strengthened halocline, the declined bioturbation by the lowered abundance or total absence of burrowing animals caused by the worsened oxygen conditions (Fig. 4b) has weakened the ventilation of the sediment surface and further increased the effluxes of phosphate and ammonium.

In 1996 the highest deep-water salinity of the 1990s was observed both in the central (8.9 PSU; Alenius et al., 1998) and the eastern gulf (7.5 PSU; Fig. 3a). After 1996 the deep-water oxygen conditions slowly improved, but a new collapse took place in 2001. Also this event was connected with the strengthened halocline, and again clearly increased deep-water salinities were measured, although slightly lower than in 1996. However, no saline water pulses from the North Sea were recorded before this event, but the increased deep-water salinities must have been caused by the increased inflow of saline water from the Baltic Proper to the Gulf of Finland and/or weakened vertical mixing.

Poor oxygen conditions have occurred also earlier in the Gulf of Finland. Already Gripenberg (1934) reported grey or black sediment surfaces with a smell of hydrogen sulphide in the year 1924 and Stenij (1929) reported poor oxygen conditions in the year 1928 in the Gulf of Finland. In the western and central parts of the gulf, the period from the late 1960s to the mid-1980s was characterized by poor oxygen conditions below $60 \mathrm{~m}$ and even occurrence of $\mathrm{H}_{2} \mathrm{~S}$ deeper. This also led to the deterioration of macrozoobenthos in the earlier colonized areas (Andersin \& Sandler, 1991).

The area of reduced surface sediments seems to vary considerably from year to year, depending on the mixing conditions in those parts of the eastern gulf that accumulate organic matter. Especially the relatively shallow eastern main basin of the gulf is sensitive to strong changes of oxygen conditions at the sedimentwater interface (Pitkänen et al., 2001). In some autumns vertical mixing caused by strong winds can break the salinity stratification down to bottom in the deep $(60-70 \mathrm{~m})$ parts of the eastern gulf. When the deep water remains unmixed in some years, the probability of anoxia at the sediment-water interface will increase during the following late summer/early autumn.

The measured voluminous efflux of DIP is related to the fact that in anoxic conditions the cycling of iron may be inactivated by hydrogen sulphide formed in microbial sulphate reduction and the following FeS formation in brackish sediments. The FeS formation, indicated by the black sediment surface, leads to very low dissolved Fe concentration in relation to that of DIP in pore waters. The amount of newly formed $\mathrm{Fe}$ (III) oxides from the amount of upward diffusing $\mathrm{Fe}$ 
is not sufficient to bind all the upward diffusing DIP and, as a result, a high release of $\mathrm{P}$ to the near-bottom water will happen (Gunnars \& Blomqvist, 1997; Lehtoranta \& Heiskanen, 2003).

\section{Critical factors affecting the $P$ budget}

The observed change in the nutrient dynamics of the Gulf of Finland that has been going on since the early 1990s is not coupled to changes in the external loading, which has been decreasing since the late 1980s (Pitkänen et al., 2001). The wintertime open gulf data suggest increasing phosphate-P but decreasing inorganic $\mathrm{N}$ trends since the beginning of the 1990s (Lips et al., 2002).

According to the wintertime monitoring data, the average phosphate- $\mathrm{P}$ concentration of the mixed winter surface layer increased by about $10 \mu \mathrm{g} / \mathrm{L}$ between the winters of 2001 and 2002 (Fig. 7). For the deeper layers the corresponding change was clearly higher according to the data from the middle part of the gulf (Perttilä, 2003). Assuming that the average increase of $10 \mu \mathrm{g} / \mathrm{L}$ has been valid for the whole water volume of the gulf $\left(\right.$ about $\left.1100 \mathrm{~km}^{3}\right)$, the interannual change in the phosphate-P content of the water mass of the sea area was about $11000 \mathrm{t} / \mathrm{yr}$ between the winters of 2001 and 2002.

The total land-based load of P to the Gulf of Finland is $6400 \mathrm{t} / \mathrm{yr}$ (Kiirikki et al., 2003), i.e. the total load is clearly smaller than the estimated increase in the DIP content. The important fraction of total $\mathrm{P}$ is the bioavailable DIP. According to the available monitoring data, the estimated annual external input of bioavailable $\mathrm{P}$ into the gulf is $2900 \mathrm{t} / \mathrm{yr}$ (Kiirikki et al., 2003), i.e. less than $30 \%$ of the estimated change in the DIP content of the gulf. Thus, changes in external loads from the catchment cannot explain the increase in the DIP content even if there were large errors in the load assessments. A similar conclusion on the strong role of the internal $\mathrm{P}$ loading over the changes in the external loading was made also for the whole Baltic Sea (Conley et al., 2002).

There are only two factors in the P budget of the whole Gulf of Finland that could cause such dramatic concentration and mass changes in the whole water body between two succeeding years. These are the net transport from the Baltic Proper to the Gulf of Finland, and the net exchange between sediment and water. On the basis of the salinity and phosphorus data of the Finnish Institute of Marine Research in 2000-02 at the entrance to the gulf, a rough estimate for the net influx to the gulf of $8000 \mathrm{t} / \mathrm{yr}$ of total $\mathrm{P}$ can be obtained by the Knudsen formula. Similarly, Perttilä et al. (1995) calculated the net influx of $8000 \mathrm{t} / \mathrm{yr}$ of total P using data of the years 1990-92, when good deep-water oxygen conditions prevailed. Despite the same estimates for the two periods, the obtained figures can only represent the order of magnitude of the real exchange, due to many uncertainties in the use of the Knudsen formula.

When we use the mean value of the DIP efflux of $13 \mathrm{mg} \mathrm{P} / \mathrm{m}^{2}$ per day based on the experimental data of Lehtoranta (2003) (Fig. 5) and presume that $2 / 3$ 
$\left(6000 \mathrm{~km}^{2}\right.$ ) of the estimated total accumulation bottom of $9000 \mathrm{~km}^{2}$ (Kankaanpää, 1997) was in reduced state in summer-autumn 2001, a total daily sediment efflux of about 80 tonnes is obtained for the gulf. According to studies of Lehtoranta \& Heiskanen (2003) off the northwestern Finnish coast at a depth of $50 \mathrm{~m}$, the anoxic period lasts about 4 months (120 days). If this result is applied for the whole gulf, a total efflux of the order of 10000 tonnes of DIP will be obtained, which is in accordance with the estimation on the mass change of DIP between the winters of 2001 and 2002 based on monitoring data (Fig. 7). Lehtoranta (2003) estimated by using an annual average efflux of $2.0 \mathrm{mg} \mathrm{P} / \mathrm{m}^{2}$ per day that the gross efflux of DIP would vary between 4000 and 18000 tonnes of $\mathrm{P}$ annually depending on the area of oxidized/reduced sediment surface.

It seems evident that the sediment efflux can strongly affect the annual $\mathrm{P}$ balance and the dynamics of the Gulf of Finland and counteract the changes in the external P loading. This is verified both by inter-annual concentration changes and experimental results.

\section{CONCLUSIONS}

In its present state the Gulf of Finland is very sensitive to increased sediment effluxes of nutrients, especially those of inorganic P. Although also the ammonium efflux is considerable, the inorganic $\mathrm{N}$ : $\mathrm{P}$ ratio (from 1 to 3 by weight) of the sediment nutrient efflux is strongly below the Redfield optimum of 7 , which suggests that the intensified sediment efflux probably was responsible for the observed extensive blue-green algal blooms in the gulf in the late 1990s and early 2000s.

In the time scale of a few years this phenomenon is the most important factor affecting the recent eutrophication development of the gulf, measured as intensified blooms of cyanobacteria (Kahru et al., 2000) and increased total biomass of algae in summer (Kauppila \& Lepistö, 2001). The sediment P efflux seems to be connected with the availability of oxygen at the sediment-water interface, which is affected by vertical density stratification, the amount and quality of benthic fauna, and the amount of organic matter sedimentation.

The actual chemical and microbial processes controlling the sediment $\mathrm{P}$ release are poorly understood (Roden \& Edmonds, 1997; Golterman, 2001). It seems possible that the poor $\mathrm{P}$ binding capacity of the sediments in the Gulf of Finland are related to microbial reduction rates of iron(III) oxide and sulphate, and to the factors controlling these processes, e.g. the availability of labile organic matter (Lehtoranta, 2003). This would mean that the reduction of the sediment $\mathrm{P}$ release can happen only via decreased sedimentation of easily degradable organic matter produced in pelagic primary production. The only way to decrease autochthonous production of organic matter is to further reduce external nutrient inputs both directly to the Gulf of Finland and to the Baltic Proper, which is an important source of nutrients for the gulf. 


\section{ACKNOWLEDGEMENTS}

The present paper is an outcome of the joint Finnish-Estonian-Russian project "Benthic oxygen conditions in the regulation of the state of the Gulf of Finland" coordinated by the Finnish Environment Institute (SYKE). The external funding of the project is mainly provided by the Ministry of Environment, the Unit of Environmental Co-operation in Central and Eastern Europe. Additional funding has been obtained from WWF-Finland. We thank the two anonymous referees for the constructive comments.

\section{REFERENCES}

Alenius, P., Myrberg, K. \& Nekrasov, A. 1998. The physical oceanography of the Gulf of Finland: a review. Boreal Env. Res., 3, 97-125.

Andersin, A.-B. \& Sandler, H. 1991. Macrobenthic fauna and oxygen deficiency in the Gulf of Finland. Mem. Soc. Fauna Flora Fenn., 67, 3-10.

Balls, P. W. 1994. Nutrient inputs to estuaries from nine Scottish east coast rivers: influence of estuarine processes on inputs to the North Sea. Est. Coastal Shelf Sci., 39, 329-352.

Caraco, N., Cole, J. \& Likens, G. E. 1990. A comparison of phosphorus immobilisation in sediments of freshwater and coastal marine systems. Biogeochemistry, 9, 277-290.

Conley, D. J., Humborg, C., Rahm, L., Savchuk, O. P. \& Wulff, F. 2002. Hypoxia in the Baltic Sea and basin scale changes in phosphorus biogeochemistry. Environ. Sci. Technol., 36, 53155320.

Elken, J., Matthäus, W., Krzyminski, W. \& Dubra, J. 2002. Meteorological, hydrological and hydrographic forcing. In HELCOM. Environment of the Baltic Sea Area 1994-1998. Baltic Sea Environ. Proc., 82B, 39-45.

Fonselius, S. 1969. Hydrography of the Baltic deep basins III. Fish. Board Swed. Ser. Hydrogr., Rep., 23.

Froelich, P. N. 1988. Kinetic control of dissolved phosphate in natural rivers and estuaries: a primer on the phosphate buffer mechanism. Limnol. Oceanogr., 33, 649-668.

Golterman, H. L. 2001. Phosphate release from anoxic sediments or 'What did Mortimer really write?'. Hydrobiologia, 450, 99-106.

Gran, V. \& Pitkänen, H. 1999. Denitrification in estuarine sediments in the eastern Gulf of Finland, Baltic Sea. Hydrobiologia, 393, 107-115.

Gripenberg, S. 1934. A study of the sediments of the north Baltic and adjoining areas. Merentutkimuslait. julk., 96.

Gunnars, A. \& Blomqvist, S. 1997. Phosphate exchange across the sediment-water interface when shifting from anoxic to oxic conditions - an experimental comparison of freshwater and brackish-marine systems. Biogeochemistry, 37, 203-226.

Hansen, K., Mouridsen, S. \& Kristensen, E. 1998. The impact of Chironomus plumosus larvae on organic matter decay and nutrient $(\mathrm{N}, \mathrm{P})$ exchange in a shallow eutrophic lake sediment following a phytoplankton sedimentation. Hydrobiologia, 364, 65-74.

Heiskanen, A., Gran, V., Lehtoranta, J. \& Pitkänen, H. 1999. Fate of nutrients (N, P) in the estuarine gradient of the River Neva in the eastern Gulf of Finland, Baltic Sea (Extended abstract). ICES J. Mar. Sci., 56 Suppl., 161-164.

HELCOM. 1998. Third Baltic Sea pollution load compilation. Baltic Sea Environ. Proc., 70.

HELCOM. 2002. Fourth periodic assessment of the state of the marine environment of the Baltic Sea 1994-1998. Baltic Sea Environ. Proc., 82A. 
Johansson, B. 1997. Behavioural response to gradually declining oxygen concentration by Baltic Sea macrobenthic crustaceans. Mar. Biol., 129, 71-78.

Kauppila, P. \& Lepistö, L. 2001. Changes in phytoplankton. In The State of Finnish Coastal Waters in the 1990s (Kauppila, P. \& Beck, S., eds.). Finn. Environ., 472, 61-70.

Kahru, M. Leppänen, J.-M., Rud, O. \& Savchuk, O. P. 2000. Cyanobacteria blooms in the Gulf of Finland triggered by saltwater inflow into the Baltic Sea. Mar. Ecol. Prog. Ser., 207, 13-18.

Kankaanpää, H. 1997. Sedimentation, distribution, sources and properties of organic halogen material in the Gulf of Finland. Monogr. Boreal Environ. Res., 6.

Kemp, W. M., Sampou, P., Caffrey, J., Mayer, M., Henriksen, K. \& Boynton, W. R. 1990. Ammonium recycling versus denitrification in Chesapeake bay sediments. Limnol. Oceanogr., 35, $1545-1563$.

Kiirikki, M., Inkala, A., Kuosa, H., Pitkänen, H., Kuusisto, M. \& Sarkkula, J. 2001. Evaluating the effects of nutrient load reductions on the biomass of toxic nitrogen-fixing cyanobaceria in the Gulf of Finland, the Baltic Sea. Boreal Environ. Res., 6, 131-146.

Kiirikki, M., Välipakka, P., Korpinen, P., Koponen, J. \& Sarkkula, J. 2002. 3D ecosystem models as decision support tools in the Gulf of Finland - the Kotka Archipelago as an example. In Baltic Coastal Ecosystems - Structure, Function and Coastal Zone Management (Schernewski, G. \& Schiewer, U., eds.), pp. 293-309. CEEDES, Springer.

Kiirikki, M., Rantanen, P., Varjopuro, R., Leppänen, A., Hiltunen, M., Pitkänen, H., Ekholm, P., Moukhametshina, E., Inkala, A., Kuosa, H. \& Sarkkula, J. 2003. Cost effective water protection in the Gulf of Finland - focus on St. Petersburg. Finn. Environ., 632 (in press).

Koroleff, F. 1976. Determination of nutrients. In Methods of Sea Water Analysis (Grasshoff, K., ed.), pp. 117-133. Verlag Chemie, Weinheim, New York.

Kotta, J., Kotta, I., Kangas, P., Laine, A. \& Andersin, A.-B. 2002. Benthic conditions. Macrozoobenthos. In HELCOM. Environment of the Baltic Sea Area 1994-1998. Baltic Sea Environ. Proc., 82B, 83-85.

Kuparinen, J. \& Tuominen, L. 2001. Eutrophication and self-purification: counteractions forced by large-scale cycles and hydrodynamic processes. Ambio, 30, 190-194.

Laine, A. O., Sandler, H., Andersin, A.-B. \& Stigzelius, J. 1997. Long-term changes of macrozoobenthos in the eastern Gotland Basin and the Gulf of Finland (Baltic Sea) in relation to the hydrographical regime. J. Sea Res., 38, 135-159.

Lehtoranta, J. 2003. Dynamics of sediment phosphorus in the brackish Gulf of Finland. Monogr. Boreal Environ. Res., 24.

Lehtoranta, J. \& Heiskanen, A.-S. 2003. Dissolved iron: phosphate ratio as an indicator of phosphate release to oxic water of the inner and outer coastal Baltic Sea. Hydrobiologia (in press).

Lips, U., Poutanen, E.-L., Pitkänen, H., Kauppila, P. \& Basova, S. 2002. Hydrochemistry. In Baltic Marine Environment Protection Commission. Fourth Periodic Assessment of the State of the Marine Environment of the Baltic Sea. Baltic Sea Environ. Proc., 82B, 76-78.

Matthäus, W. \& Lass, H. U. 1995. The recent salt inflow into the Baltic Sea. J. Phys. Oceanogr., 25, 280-286.

Modig, H. \& Ólafsson, E. 1998. Responses of Baltic invertebrates to hypoxic events. J. Exp. Mar. Biol. Ecol., 229, 133-148.

Nixon, S. W. 1995. Coastal marine eutrophication: a definition, social causes and future concerns. Ophelia, 41, 199-219.

Perttilä, M. 2003. Assessment: State of the Gulf of Finland in 2002 (A draft to be presented at the Trilateral Gulf of Finland Meeting, 19-20 March 2003 St. Petersburg). Meri - Rep. Ser. Finn. Inst. Mar. Res., 48, 48-55.

Perttilä, M., Niemistö, L. \& Mäkelä, K. 1995. Distribution, development and total amounts of nutrients in the Gulf of Finland. Estuar. Coastal Shelf Sci., 41, 345-360.

Pitkänen, H. \& Tamminen, T. 1995. Nitrogen and phosphorus as production limiting factors in the estuarine waters of the eastern Gulf of Finland. Mar. Ecol. Prog. Ser., 129, 283-294. 
Pitkänen, H., Tamminen, T., Kangas, P., Huttula, T., Kivi, K., Kuosa, H., Sarkkula, J., Eloheimo, K., Kauppila, P. \& Skakalsky, B. 1993. Late summer trophic conditions in the north-east Gulf of Finland and the River Neva Estuary, Baltic Sea. Estuar. Coastal Shelf Sci., 37, 453-474.

Pitkänen, H., Lehtoranta, J. \& Räike, A. 2001. Internal nutrient fluxes counteract decreases in external load: the case of the estuarial Gulf of Finland. Ambio, 30, 195-201.

Prastka, K., Sanders, R. \& Jickells, T. 1998. Has the role of estuaries as sources or sinks of dissolved inorganic phosphorus changed over time? Results of a $K_{\mathrm{d}}$ study. Mar. Pollut. Bull., 36, 718-728.

Roden, E. E. \& Edmonds, J. W. 1997. Phosphate mobilization in iron-rich anaerobic sediments: microbial Fe(III) oxide reduction versus iron-sulphide formation. Arch. Hydrobiol., 139, 347-378.

Rosenberg, R. 2001. Marine benthic faunal successional stages and related sedimentary activity. Sci. Marina, 65 (Suppl. 2), 107-119.

Savchuk, O. \& Wulff, F. 1999. Modelling regional and large scale responses of the Baltic Sea ecosystems to nutrient reductions. Hydrobiologia, 393, 35-43.

Seitzinger, S. P. 1988. Denitrification in freshwater and coastal marine ecosystems: ecological and geochemical significance. Limnol. Oceanogr., 33, 702-724.

Stenij, S. E. 1929. Croisiere thalassologique et observations en bateaux routiers en 1928. Merentutkimuslaitoksen julk./Havsforskningsinst. skr., 66.

Tuominen, L., Heinänen, A., Kuparinen, J. \& Nielsen, L. P. 1998. Spatial and temporal variability of denitrification in the sediments of the northern Baltic Proper. Mar. Ecol. Progr. Ser., 172, 13-24.

Ærteberg et al. 2001. Eutrophication in Europe's coastal waters. European Environment Agency. Topic report no. 7.

\title{
Põhjasettest pärinev fosfor ja selle mõju Soome lahe keskkonnaseisundile 2000. aastate algul
}

\author{
Heikki Pitkänen, Jouni Lehtoranta, Heikki Peltonen, Ari Laine, \\ Jonne Kotta, Ilmar Kotta, Pavel Moskalenko, Anita Mäkinen, \\ Pentti Kangas, Matti Perttilä ja Mikko Kiirikki
}

Fosfori kontsentratsiooni ja bilanssi on Soome lahes alates 1990. aastate teisest poolest oluliselt mõjutanud põhjasettest pärinev fosfor, mille voog kasvas keemiliselt redutseeritud tingimuste tõttu vee ja sette vahelises piirikihis eriti 1996. ja 2001. aasta hilissuvel ja sügisel. Fosfaatide koguvoog põhjasettest võib mitmeid kordi ületada lahe valgalalt pärinevat koguvoogu. Sisemist fosforikoormust (fosfori koguvoogu põhjasettest) mõjutavad veesamba kihistus, põhjareljeef, orgaanilise aine sisaldus sette ülakihis ja põhjaloomastiku arvukus. Ainuke võimalus põhjasettest pärinevat fosforikoormust vähendada on primaarproduktsiooni ja orgaanilise aine settimise kahandamine. Selleks on vaja piirata nii Soome lahte kui ka Ava-Läänemerre suubuvat välist, maismaalt pärinevat toitainete koormust. 